\title{
Catalytic organosolv fractionation of willow wood and wheat straw as pretreatment for enzymatic cellulose hydrolysis
}

\author{
W.J.J. Huijgen \\ A.T. Smit \\ J.H. Reith \\ H. den Uil
}

Published online in Wiley Online Library: (wileyonlinelibrary.com) DOI 10.1002/jctb.2654 


\title{
Catalytic organosolv fractionation of willow wood and wheat straw as pretreatment for enzymatic cellulose hydrolysis
}

\author{
Wouter J. J. Huijgen, ${ }^{*}$ Arjan T. Smit, Johannes H. Reith and Herman den Uil
}

\begin{abstract}
BACKGROUND: Ethanol-based organosolv fractionation of lignocellulosic biomass is an effective pretreatment technology for enzymatic cellulose hydrolysis to produce sugars and lignin within a biorefinery. This study focuses on the catalytic effect of $\mathrm{H}_{2} \mathrm{SO}_{4}, \mathrm{HCl}$, and $\mathrm{MgCl}_{2}$ on organosolv pretreatment of willow wood and wheat straw.

RESULTS: The use of catalysts improved fractionation of both feedstocks. The maximum enzymatic cellulose digestibility obtained was $87 \%$ for willow wood (using $0.01 \mathrm{~mol} \mathrm{~L}^{-1} \mathrm{H}_{2} \mathrm{SO}_{4}$ as catalyst) and $99 \%$ for wheat straw $\left(0.02 \mathrm{~mol} \mathrm{~L}^{-1} \mathrm{HCl}\right) . \mathrm{Non}-$ catalytic organosolv fractionation at identical conditions resulted in $74 \%$ (willow wood) and $44 \%$ (wheat straw) glucose yield by enzymatic hydrolysis. Application of catalysts in organosolv pretreatment was particularly effective for wheat straw. The influence of the acid catalysts was found to be primarily due to their effect on the $\mathrm{pH}$ of the organosolv liquor. Acid catalysts particularly promoted xylan hydrolysis. $\mathrm{MgCl}_{2}$ was less effective than the acid catalysts, but it seemed to more selectively improve delignification of willow wood.
\end{abstract}

CONCLUSION: Application of catalysts in organosolv pretreatment of willow wood and wheat straw was found to substantially improve fractionation and enzymatic digestibility. The use of catalysts can contribute to achieving maximum utilization of lignocellulosic biomass in organosolv-based biorefineries.

(c) 2011 Society of Chemical Industry

Keywords: organosolv; catalyst; pretreatment; fractionation; enzymatic hydrolysis; wheat straw; willow wood

\section{INTRODUCTION}

Organosolv fractionation of lignocellulosic biomass has been widely studied as a pretreatment technology for enzymatic cellulose hydrolysis within a biorefinery to produce fermentable sugars and high-purity lignin., ', 'Organosolv' was originally developed as pulping technology for paper production ${ }^{3}$ and comprises a class of processes in which lignocellulosic biomass is treated with an organic solvent at elevated temperatures. In the case of application of organosolv as pretreatment technology, the function of the organic solvent is to delignify the lignocellulosic biomass prior to enzymatic cellulose hydrolysis. ${ }^{1}$ Thus, the enzymatic digestibility of the biomass is improved by reducing the recalcitrance of the biomass as well as minimizing the non-productive binding of hydrolytic enzymes to lignin..$^{1,2,4}$ The extracted lignin fraction can be recovered from the organosolv liquor for further processing. ${ }^{1,5}$ Organosolv lignins tend to have a high purity and be essentially free of sulphur and ash. Moreover, the functionalities of native lignin are largely preserved in organosolv lignins. ${ }^{6,7}$ These characteristics are beneficial for the possible conversion of lignin into valuable products such as aromatic chemicals, resins, and antioxidants. ${ }^{8-11}$ The valorization potential of the lignin fraction is a major benefit of the organosolv process compared with other pretreatment technologies like steam explosion and mild acid pretreatment. ${ }^{1,4}$ In order to be cost-competitive with these other pretreatment technologies, valorization of the organosolv lignin has to compensate for the higher costs of the organosolv process due to, for example, the required solvent recycling. ${ }^{1,4}$ Finally, the third major structural constituent of lignocellulosic biomass, hemicellulose, is converted during the organosolv process into sugars and sugar derivatives like furfural. ${ }^{1,4}$

Various organic solvents have been used for organosolv including alcohols (such as methanol and ethanol), acetone, and organic acids (such as formic and acetic acid). ${ }^{1}$ Ethanol has been studied extensively both at lab-scale ${ }^{1}$ and at pilotscale (Lignol ${ }^{12,13}$ ). Ethanol-based organosolv pretreatment has been successfully applied to all major types of lignocellulosic biomass: hardwoods (e.g. poplar ${ }^{14}$ and olive tree ${ }^{15}$ ), softwoods (e.g. pine ${ }^{16}$ and a mixture of spruce, pine, and Douglas fir ${ }^{13}$ ), and herbaceous crops (e.g. miscanthus ${ }^{17}$ and sugar cane bagasser ${ }^{18}$ ). If ethanol-based organosolv is carried out without the use of an additional catalyst, the process is often termed autocatalytic. Acetic acid is formed during the organosolv process from acetyl side groups of the hemicellulose. Subsequently, this acid acts as a catalyst by lowering the $\mathrm{pH}$ of the organosolv liquor. However,

Correspondence to: Wouter J.J.Huijgen, Energy research Centre of the Netherlands (ECN), Biomass, Coal \& Environmental Research. P.O. Box 1, 1755 ZG, Petten, The Netherlands. E-mail: huijgen@ecn.nl

Energyresearch Centre of the Netherlands (ECN), Biomass, Coal \& Environmental Research. P.O. Box 1, 1755 ZG, Petten, The Netherlands 
the autocatalytic effect of acetic acid might not be effective enough depending on, among others, the type of biomass and limitations of other process conditions, such as reaction temperature. In those cases, the addition of a catalyst might be required. Examples of catalysts that have been studied for alcoholbased organosolv pulping and pretreatment are: mineral acids (e.g. $\mathrm{H}_{2} \mathrm{SO}_{4}, \mathrm{HCl}, \mathrm{H}_{3} \mathrm{PO}_{4}$ ), organic acids (e.g. formic and acetic acid), bases (e.g. $\mathrm{NaOH}$ ) and salts (e.g. $\mathrm{MgCl}_{2}$ ). ${ }^{1,3}$ Catalysts have been reported to promote hemicellulose hydrolysis, ${ }^{4,19}$ cleavage of ether bonds within the lignin fraction (delignification), ${ }^{10,20}$ and enzymatic cellulose digestibility. ${ }^{19,21}$ Possible drawbacks of (acid) catalysts include costs of catalysts, corrosion issues, ${ }^{3,21}$ and promotion of carbohydrate and lignin degradation and condensation reactions $s^{1,22}$ resulting in increased formation of fermentation inhibitors like furfural. ${ }^{4,21}$

Although numerous studies have been published on catalytic organosolv, only a few compare the effect of different catalysts on a specific type of lignocellulosic biomass. Moreover, these studies are mainly limited to organosolv treatment of softwoods. For example, Yawalata and Paszner studied the effect of different chlorine salts, ${ }^{23}$ magnesium salts, ${ }^{22}$ and acid catalysts ${ }^{22}$ on methanol-based organosolv pulping of spruce. They obtained optimum results with $\mathrm{MgCl}_{2}$. Besides, $\mathrm{H}_{2} \mathrm{SO}_{4}$ and $\mathrm{HCl}$ were found to be capable of liberating the fibres. ${ }^{22}$ Park et al. tested the use of sulphuric acid, magnesium chloride, and sodium hydroxide in ethanol-based organosolv pretreatment of pitch pine. ${ }^{21}$ The use of sulphuric acid was reported to give the highest theoretical ethanol yield based on the enzymatic cellulose digestibility obtained. Finally, Del Rio et al. reported on organosolv pretreatment of mountain pine beetlekilled lodgepole pine using ethanol and butanol as solvents and various catalysts including $\mathrm{MgCl}_{2}$ and $\mathrm{H}_{2} \mathrm{SO}_{4} \cdot{ }^{19}$ They found that acid pretreatment led to pulps that were readily hydrolyzed by enzymes due to a lower degree of cellulose polymerization, shorter fibre lengths, and increased substrate porosity.

The objective of this work is to study the effect of different catalysts on organosolv pretreatment of both a hardwood (willow wood) and a herbaceous crop (wheat straw). Their effect on both the fractionation degree and enzymatic cellulose digestibility was studied. Both acid and non-acid catalysts, which are common for organosolv pulping and pre-treatment, were used (i.e. $\mathrm{H}_{2} \mathrm{SO}_{4}, \mathrm{HCl}$, and $\mathrm{MgCl}_{2}$ ). Finally, a comparison of the effect of the different catalysts was made for both feedstocks.

\section{MATERIALS AND METHODS Feedstocks}

Two types of lignocellulosic biomass were used for this study: willow wood and wheat straw. Willow wood was selected as hardwood species because it is considered a potential energy crop within The Netherlands. Willow wood was received as $<3 \mathrm{~cm}$ ambient-dry chips from Oostvaardershoeve, Slootdorp, The Netherlands, and was milled with a cutting mill (Retsch SM 2000) to $<0.5 \mathrm{~mm}$. Wheat straw was selected because it is an abundant agricultural residue in Europe. In addition, it currently has limited commercial value. ${ }^{24}$ Winter wheat straw was kindly provided by Wageningen UR - Food \& Biobased Research, Wageningen, The Netherlands and received ambient-dry and cut to $<2 \mathrm{~cm}$. Both feedstocks were stored in closed vessels at room temperature until use.

For organosolv experiments, a representative sample was taken and used without further treatment. The moisture content of the feedstocks was determined regularly either by drying at
Table 1. Composition lignocellulose feedstocks Biomass

Composition (\% w/w dry biomass) Willow wood Wheat straw

\begin{tabular}{|c|c|c|c|c|}
\hline \multirow[t]{12}{*}{ Biochemical } & Extractives & $\mathrm{H}_{2} \mathrm{O}$ & 4.4 & 8.4 \\
\hline & & $\mathrm{EtOH}$ & 1.1 & 2.0 \\
\hline & Polysaccharides & Arabinan & 1.1 & 1.9 \\
\hline & & Xylan & 11.7 & 19.9 \\
\hline & & Mannan & 1.4 & 0.2 \\
\hline & & Galactan & 1.1 & 0.7 \\
\hline & & Glucan & 32.9 & 36.9 \\
\hline & & Rhamnan & 0.4 & 0.1 \\
\hline & Lignin & AIL & 28.5 & 16.7 \\
\hline & & ASL & 2.1 & 1.1 \\
\hline & Ash & & 4.1 & 6.1 \\
\hline & Sum & & 88.8 & 93.8 \\
\hline \multirow[t]{15}{*}{ Elemental $^{\mathrm{a}}$} & C & & 48.0 & 44.3 \\
\hline & $\mathrm{H}$ & & 5.5 & 5.4 \\
\hline & $\mathrm{N}$ & & 0.6 & 0.3 \\
\hline & $\mathrm{O}$ & & 42.6 & 42.7 \\
\hline & $\mathrm{Al}$ & & 0.067 & 0.004 \\
\hline & $\mathrm{Ca}$ & & 0.614 & 0.236 \\
\hline & $\mathrm{Cl}$ & & 0.027 & 0.022 \\
\hline & $\mathrm{Fe}$ & & 0.056 & 0.005 \\
\hline & K & & 0.350 & 0.289 \\
\hline & $\mathrm{Mg}$ & & 0.072 & 0.039 \\
\hline & $\mathrm{Na}$ & & 0.045 & 0.017 \\
\hline & $P$ & & 0.112 & 0.030 \\
\hline & $S$ & & 0.064 & 0.052 \\
\hline & Si & & 0.233 & 2.238 \\
\hline & Sum & & 98.3 & 95.6 \\
\hline
\end{tabular}

${ }^{a}$ Other elements measured $<0.01 \% \mathrm{w} / \mathrm{w}$ dry biomass.

$105^{\circ} \mathrm{C}$ according to protocol NREL/TP-510-4262 $1^{25}$ (willow wood) or using a halogen moisture analyzer (Mettler Toledo HR83, Columbus, $\mathrm{OH}$ ) (wheat straw). The average moisture content of the willow wood and wheat straw raw materials was $\sim 10 \%$ and $\sim 9 \%$, respectively ( $\mathrm{w} / \mathrm{w}$ dry biomass, variations in moisture content for both feedstocks were $<1 \%$ ). The composition of both feedstocks is given in Table 1. The biochemical composition of the feedstocks was determined as described in the section 'composition analysis of solids'. The elemental composition was measured with an elemental analyzer (Carlo Erba Instruments FLASH EA 1112, Wigan, UK) $(\mathrm{C}, \mathrm{H}, \mathrm{N}$, and $\mathrm{O})$, ion chromatography after bomb combustion $(\mathrm{Cl})$, and inductively coupled plasma atomic emission spectroscopy (ICP-AES) (other elements).

Finally, the acid neutralizing capacity (ANC) of both feedstocks was determined according to CEN TS $14429^{26}$ using a final pH of 2 and measurement time of $48 \mathrm{~h}$. The ANC was $0.36 \mathrm{~mol}$ $\mathrm{H}^{+} \mathrm{kg}^{-1}$ dry biomass for willow wood and $0.26 \mathrm{~mol} \mathrm{H}^{+} \mathrm{kg}^{-1}$ dry biomass for wheat straw. The difference in ANC is probably caused by a difference in composition of the mineral fraction of both feedstocks. The mineral fraction of the wheat straw mainly consists of Si (Table 1). The major element in the mineral fraction of the willow wood is $\mathrm{Ca}$, which provides alkalinity. Thus the ANC of willow wood is higher than that of wheat straw in spite of the lower ash content of willow (Table 1). 


\section{Selection of catalysts}

Three different catalysts were selected for this study: $\mathrm{H}_{2} \mathrm{SO}_{4}, \mathrm{HCl}$, and $\mathrm{MgCl}_{2}$. Sulphuric acid is the acid catalyst most often used for organosolv fractionation of various types of lignocellulose, both for pulping ${ }^{3}$ and for pretreatment prior to enzymatic cellulose hydrolysis. ${ }^{1} \mathrm{HCl}$ was used as alternative acid, since it has been reported to be effective in methanol, ethanol, and acetic acid-based (Acetosolv) organosolv pulping. ${ }^{3}$ Finally, $\mathrm{MgCl}_{2}$ was selected as a non-acid catalyst based on work by Yawalata and Paszner. ${ }^{22,23}$ They reported $\mathrm{MgCl}_{2}$ to be the optimum catalyst in an extensive study on the catalytic effect of various salts on methanolbased organosolv pulping of spruce wood for paper applications (neutral alkali earth metal (NAEM) process).22,23 Although limited information about the (potential) catalytic mechanism of $\mathrm{MgCl}_{2}$ is available, ${ }^{27}$ its catalytic effect on the organosolv process has been confirmed by other authors, particularly for softwood pulping. ${ }^{19,21}$

\section{Organosolv experiments}

Organosolv experiments were performed in six parallel $125 \mathrm{~mL}$ batch reactors (acid digestion bomb type 4748, SS 316 with Teflon liner, Parr Instrument Company, Moline, IL). $6 \mathrm{~g}$ (as received) lignocellulose was mixed with $31 \mathrm{~g}$ ethanol (ethanol $96 \%$, Merck, purity: $92.6-95.2 \%$ w/w, average $94 \%$ w/w used within calculations), $21 \mathrm{~g}$ demineralized water and a catalyst. The resulting ethanol-water ratio was $55-56 \% \mathrm{w} / \mathrm{w}$ including moisture content of the feedstock. The liquid-solid (L/S)-ratio was $9.5-9.7 \mathrm{~kg} \mathrm{~kg}^{-1}$ dry biomass for all experiments. A catalyst was added in a concentration of $0-0.025 \mathrm{~mol} \mathrm{~L}^{-1}\left(\mathrm{H}_{2} \mathrm{SO}_{4}\right), 0-0.05 \mathrm{~mol} \mathrm{~L}^{-1}(\mathrm{HCl})$ or $0-0.1 \mathrm{~mol} \mathrm{~L}^{-1}\left(\mathrm{MgCl}_{2}\right)$. The acid catalysts were added in equal normalities $(0-0.05 \mathrm{~N})$ to enable direct comparison. The closed reactor vessels were placed in a heating block (adapted RS600, Thermo Fisher Scientific, Rochford, UK) and the block temperature was set at $190^{\circ} \mathrm{C}$. Stirring was provided by a magnetic stir bar at the bottom of the vessels (1000 rpm). Visual tests with model slurries showed that the mixing in the reactor was adequate, except at the beginning of an experiment. After $180 \mathrm{~min}$, the heating block was switched off and the reactors were allowed to cool down. Experiments were performed overnight with fixed start and end time.

The experimental set-up used did not allow measurement of the internal reactor temperature during the organosolv experiments. As an estimate of the development of this temperature, Fig. 1 shows the average internal temperature profile of two reactors filled with $75 \mathrm{~mL}$ Shell Thermia oil B (recorded with a thermocouple, identical settings as for organosolv experiments). The average maximum reactor temperature measured was $187^{\circ} \mathrm{C}$. A pretreatment severity factor $\left(\log R_{0}\right)$ of 4.65 was calculated by integration over the entire temperature profile $\left(R_{0}=\sum e^{\frac{T-T_{\text {ref }}}{14.75}} \cdot \Delta t\right.$ with $\left.\mathrm{T}_{\text {ref }}=100^{\circ} \mathrm{C}\right) .{ }^{28}$ Temperature differences between the six individual reactors were estimated to be less than $2^{\circ} \mathrm{C}$ for all experiments.

After organosolv treatment, the suspension was filtered quantitatively over a Whatman GF/D filter and the $\mathrm{pH}$ of the organosolv liquor was measured at room temperature as an approximation of its hydrogen ion concentration. The solid fraction remaining after organosolv was washed with $60 \mathrm{~mL} 56 \%$ $\mathrm{w} / \mathrm{w}$ ethanol-water and dried overnight in a vacuum oven at $50{ }^{\circ} \mathrm{C}$. Drying of the pulp was performed for practical reasons and was purposely performed at mild conditions to limit its possible influence on the enzymatic digestibility of the pulp. ${ }^{29,30}$ Finally,

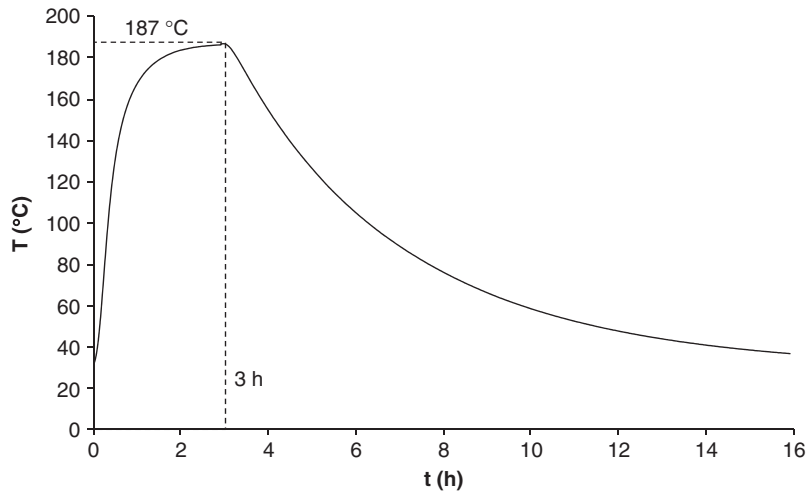

Figure 1. Average temperature profile recorded of two reactors filled with Thermia B oil (set-point: $190^{\circ} \mathrm{C}$, switch off heating after $3 \mathrm{~h}$ ).

the pulp yield was calculated (\% dw recovered solids/dw starting material).

During the wheat straw fractionation experiments, the organosolv liquor and the washing solution were combined and analyzed for their composition. Monomeric sugars including glucose and xylose were determined with high-performance anion exchange chromatography with pulsed amperometric detection (HPAECPAD) (Dionex ICS3000, Sunnyvale, CA). The sugar derivatives furfural, hydroxymethylfurfural (HMF), and levulinic acid were determined using high-performance liquid chromatography (HPLC$\mathrm{RI} / \mathrm{UV}$, with BIO RAD Aminex HPX-87H column, $65^{\circ} \mathrm{C}, 5 \mathrm{mmol} \mathrm{L}^{-1}$ $\mathrm{H}_{2} \mathrm{SO}_{4}$ ).

\section{Composition analysis of solids}

The composition of raw materials and a selection of pretreated samples were analyzed using analytical procedures published by NREL ${ }^{25}$ and TAPPI. ${ }^{31}$ The moisture content was determined using a halogen moisture analyzer (Mettler Toledo HR83). The ash content of the raw materials was measured by combustion at $550{ }^{\circ} \mathrm{C}$ according to protocol NREL/TP-510-42622. ${ }^{25}$ The biochemical composition (i.e. content of extractives, lignin, hemicelluloses, and cellulose) of these solids was determined in duplicate using a modified hydrolysis protocol based on TAPPI methods T 222 and $249 .{ }^{31}$ First, in the case of raw materials, extractives were removed with two successive Soxhlet extractions using water and ethanol (NREL/TP-510-4261925). Second, the sample was milled with a cutting mill and hydrolyzed in two steps: (1) $72 \% \mathrm{w} / \mathrm{w}_{2} \mathrm{SO}_{4}$ $\left(30{ }^{\circ} \mathrm{C}, 1 \mathrm{~h}\right)$ and $(2) 4 \% \mathrm{w} / \mathrm{w} \mathrm{H}_{2} \mathrm{SO}_{4}\left(100^{\circ} \mathrm{C}, 3 \mathrm{~h}\right)$. The solid residue was determined gravimetrically and its ash content was measured according to NREL/TP-510-42 618. ${ }^{25}$ The acid-insoluble lignin (AIL) content was based on the amount of ash-free residue. Finally, the hydrolysate was analyzed for monomeric sugars (HPAEC-PAD) as well as acid-soluble lignin (ASL, UV-VIS absorption at $205 \mathrm{~nm}$ ). Analyses of a reference sample (willow wood pretreated with noncatalytic ethanol-based organosolv), included in each series of biochemical composition analyses, yielded relative experimental errors of: AIL (1.5\%), ASL (6.3\%), glucan (2.8\%), and xylan (3.1\%) $(\sigma, \mathrm{n}=8)$. For more details about the analysis procedure and the calculation principles applied, we refer the reader to Huijgen et al. ${ }^{30}$

\section{Enzymatic digestibility}

The enzymatic digestibility of fresh and a selection of pretreated lignocellulose samples was measured in duplicate according to 
NREL/TP-510-42629..$^{25}$ The moisture content of the substrate was determined using a halogen moisture analyzer (Mettler Toledo HR83). A suspension of $0.6 \mathrm{~g}$ biomass, $20 \mathrm{~mL} 0.05 \mathrm{~mol} \mathrm{~L}^{-1}$ Na-acetate buffer ( $\mathrm{pH} 4.8)$, and an antibiotic ( $12 \mu \mathrm{L}$ PenStrep containing $5000 \mathrm{U} \mathrm{mL}^{-1}$ penicillin and $5 \mathrm{mg} \mathrm{mL}^{-1}$ streptomycin) to eliminate potential bacterial growth was shaken in an incubator. After heating to $50^{\circ} \mathrm{C}, 0.32 \mathrm{~mL}$ of enzyme was added and incubation was continued for $72 \mathrm{~h}$. The enzyme used was Accellerase 1500 (Genencor, Rochester, NY) and the cellulase activity of the enzyme batch used was $62 \mathrm{FPU} \mathrm{mL}^{-1}$, determined according to the protocol of Ghose. ${ }^{32}$ The enzyme dose used corresponds to about $33 \mathrm{FPU} \mathrm{g}{ }^{-1}$ substrate. This dose has not been optimized and is assumed to be sufficiently high to ensure an excess of enzyme. At fixed intervals, samples were taken from the mixture for glucose determination. Glucose concentrations were determined with a colorimetric protocol derived from Yee and Goodwin. ${ }^{33}$ The enzymatic glucose yield was calculated on the basis of the mean glucose concentration in the hydrolysate after $72 \mathrm{~h}$ and the glucan content of the substrate. For more details we refer the reader to our earlier work. ${ }^{30}$

A reference sample was included in each series of enzymatic hydrolysis tests. The variation in maximum glucose concentrations resulting from the reference sample within $72 \mathrm{~h}$ enzymatic hydrolysis was $3.2 \%$ between the series $(\sigma, n=4)$. The variation in glucose concentration at each time interval was $1.3-4.5 \%(\sigma, \mathrm{n}=$ 4 , excluding $t=0 \mathrm{~h}$ ).

\section{Error analysis}

In each of the three series of organosolv experiments per feedstock, an organosolv experiment in which no catalyst was added was included as a reference point (Table 2). Thus, the non-catalytic experiment was performed in triplicate for each feedstock. From its results, the experimental errors made were calculated both for fractionation degree and enzymatic digestibility. Subsequently, these errors were used as an estimate of the experimental error made in all (catalytic) organosolv experiments. All errors are based on a single standard deviation.

\section{RESULTS AND DISCUSSION}

\section{Fractionation}

Figure 2 shows the pulp yield and final $\mathrm{pH}$ of the organosolv liquor obtained from organosolv pretreatment of willow wood over the full range of catalyst concentrations applied. Based on these results, it has been decided to select $\mathrm{MgCl}_{2}$ concentrations of $0-0.025 \mathrm{~mol} \mathrm{~L}^{-1}$ for pulp composition analysis and enzymatic hydrolysis tests. First, a higher $\mathrm{MgCl}_{2}$ dose has limited effect on the pulp yield. Second, a maximum dose of $0.025 \mathrm{~mol} \mathrm{~L}^{-1}$ has also been applied for $\mathrm{H}_{2} \mathrm{SO}_{4}$, which simplifies comparison. In Table 2, the yield and composition of the pulp obtained during selected organosolv experiments are given. Figure 3 shows the corresponding fractionation degrees (i.e. xylan hydrolysis, delignification, and glucan recovery in pulp).

\section{No catalyst}

Non-catalytic organosolv, performed in triplicate for each feedstock (Table 2), has resulted in an average pulp yield of: $69.3 \pm 0.7 \%$ $\mathrm{dw}$ (willow) and $76.4 \pm 2.0 \% \mathrm{dw}$ (straw). The willow pulp consists on average of $46.6 \pm 1.2 \%$ glucan, $12.2 \pm 0.3 \%$ xylan, and $26.6 \pm 1.5 \%$ total lignin (i.e. AIL + ASL). The corresponding fractionation degrees are: xylan hydrolysis: $27.5 \pm 2.5 \%$, glucan recovery:
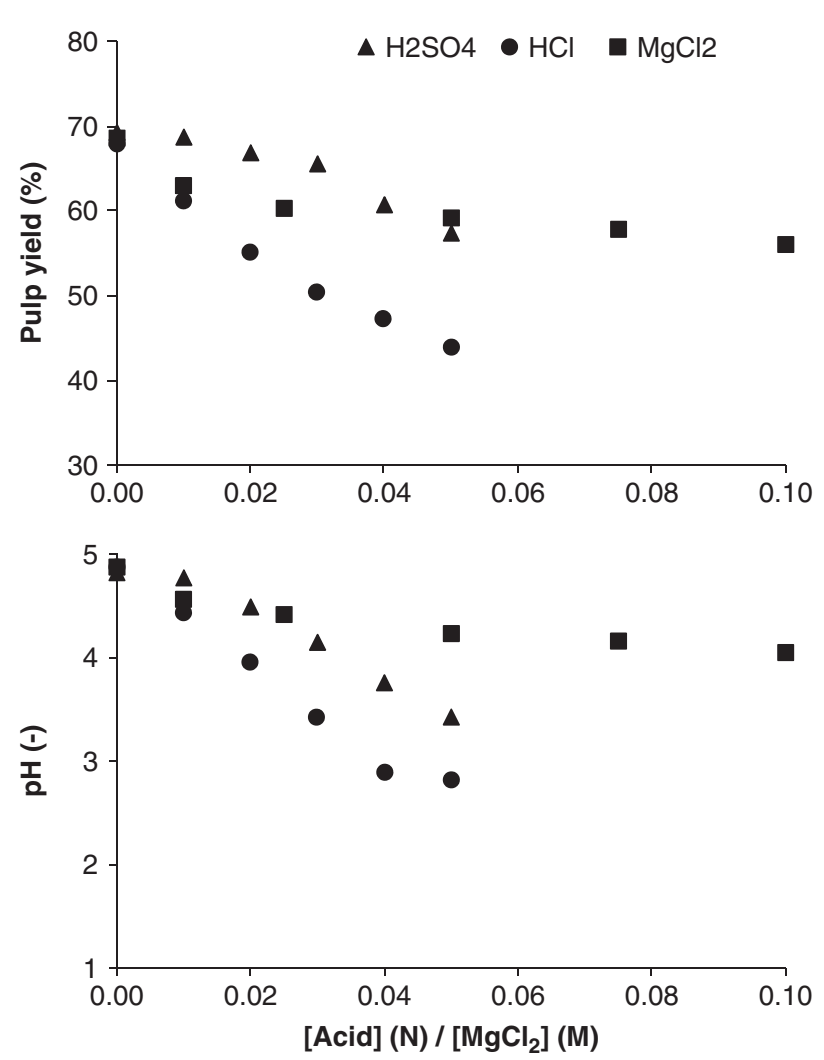

Figure 2. Pulp yield and final $\mathrm{pH}$ of liquor resulting from organosolv fractionation of willow wood as function of catalyst dose.

$98.1 \pm 1.9 \%$, and delignification: $39.6 \pm 4.0 \%$. The straw pulp contains on average $49.1 \pm 1.0 \%$ glucan, $20.3 \pm 0.3 \%$ xylan, and $16.0 \pm 0.8 \%$ total lignin, resulting in the following fractionation degrees; xylan hydrolysis: $21.8 \pm 1.8 \%$, glucan recovery: $101.8 \pm 1.2 \%$, and delignification: $31.2 \pm 5.1 \%$. Based on these numbers, the organosolv experiments performed seem reproducible. The delignification degree has the largest experimental uncertainty. These experimental uncertainties are used in Fig. 3 as an estimate of the experimental error made. Finally, during non-catalytic organosolv experiments, the $\mathrm{pH}$ of the organosolv liquor decreases to 4.8-4.9 by formation of acetic acid for both feedstocks (Table 2).

\section{Acid catalysts}

Addition of an acid catalyst $\left(\mathrm{H}_{2} \mathrm{SO}_{4}\right.$ or $\left.\mathrm{HCl}\right)$ reduces the $\mathrm{pH}$ of the organosolv liquor (Table 2) and thereby lowers the pulp yield of the organosolv pretreatment step for both feedstocks (Fig. 3). Acid catalysts particularly promote xylan hydrolysis up to $96 \%$ and $99 \%$ for willow wood and wheat straw, respectively $\left(0.05 \mathrm{~mol} \mathrm{~L}^{-1}\right.$ $\mathrm{HCl})$. In addition, acid catalysts increase delignification up to $59 \%\left(0.05 \mathrm{~mol} \mathrm{~L}^{-1} \mathrm{HCl}\right)$ and $74 \%\left(0.025 \mathrm{~mol} \mathrm{~L}^{-1} \mathrm{H}_{2} \mathrm{SO}_{4}\right)$ for willow wood and wheat straw, respectively (Fig. 3). The splitting of $\alpha$ and $\beta$-ether linkages within the lignin molecule are known to be acid-catalysed reactions. ${ }^{34}$ At (too) high acid concentrations, the glucan fraction of the biomass is partly hydrolyzed (up to $38 \%$ in the case of $0.05 \mathrm{~mol} \mathrm{~L}^{-1} \mathrm{HCl}$ and wheat straw). Based on the $\mathrm{pH}$ values given in Table 2, it can be concluded that the final $\mathrm{pH}$ of the organosolv liquor should not be lower than about 3.5 in order to avoid cellulose hydrolysis. Yawalata and Paszner claimed a pH of about 4 to be optimal for organosolv pulping. ${ }^{22}$ 


\begin{tabular}{|c|c|c|c|c|c|c|c|c|c|c|c|c|c|c|c|c|}
\hline \multicolumn{5}{|c|}{ Experimental conditions } & \multicolumn{2}{|c|}{$\mathrm{pH}$ liquor } & \multirow{3}{*}{$\begin{array}{l}\text { Pulp yield } \\
\qquad \%)^{c}\end{array}$} & \multicolumn{8}{|c|}{ Biochemical composition $\left(\%^{\mathrm{c}}\right)$} & \\
\hline \multirow[b]{2}{*}{ Biomass } & \multirow[b]{2}{*}{ Catalyst } & \multicolumn{3}{|c|}{ Dose } & \multirow{2}{*}{$\begin{array}{c}\text { Before }^{\mathrm{a}} \\
(-)\end{array}$} & \multirow{2}{*}{$\begin{array}{c}\text { Final }^{b} \\
(-)\end{array}$} & & \multicolumn{5}{|c|}{ Polysaccharides } & \multicolumn{2}{|c|}{ Lignin } & \multicolumn{2}{|c|}{ Ash $^{\mathrm{e}}$} \\
\hline & & (M) & $(\mathrm{N})$ & $(\%)^{c}$ & & & & $\mathrm{Ara}^{\mathrm{d}}$ & Xyl & Man & Gal & Glu & AlL & ASL & & Total \\
\hline \multirow{9}{*}{ Willow wood } & $\mathrm{H}_{2} \mathrm{SO}_{4}$ & 0 & 0 & 0.0 & 5.9 & 4.8 & 69.3 & f & 12.4 & 1.7 & 0.4 & 47.5 & 24.6 & 0.9 & 1.6 & 89.0 \\
\hline & & 0.010 & 0.020 & 1.1 & 3.0 & 4.5 & 66.9 & & 10.3 & 1.6 & 0.2 & 49.0 & 24.4 & 0.7 & 2.1 & 88.4 \\
\hline & & 0.025 & 0.050 & 2.7 & 2.3 & 3.4 & 57.5 & & 5.5 & 1.5 & 0.1 & 53.3 & 26.4 & 0.4 & 2.6 & 89.7 \\
\hline & $\mathrm{HCl}$ & 0 & 0 & 0.0 & 5.8 & 4.9 & 70.0 & & 12.4 & 1.6 & 0.4 & 45.2 & 27.3 & 1.0 & 2.8 & 90.7 \\
\hline & & 0.020 & 0.020 & 0.8 & 2.4 & 4.0 & 55.1 & & 5.8 & 1.3 & 0.1 & 52.9 & 26.8 & 0.5 & 2.5 & 90.0 \\
\hline & & 0.050 & 0.050 & 2.0 & 1.8 & 2.8 & 44.0 & & 1.1 & 1.0 & 0.1 & 60.1 & 28.3 & 0.3 & 2.8 & 93.8 \\
\hline & $\mathrm{MgCl}_{2}$ & 0 & & 0.0 & 5.8 & 4.9 & 68.7 & & 11.8 & 1.7 & 0.4 & 47.2 & 25.1 & 0.9 & 2.1 & 89.1 \\
\hline & & 0.010 & & 1.1 & 4.8 & 4.6 & 63.0 & & 8.7 & 1.7 & 0.2 & 50.9 & 25.2 & 0.7 & 2.2 & 89.6 \\
\hline & & 0.025 & & 2.7 & 4.8 & 4.4 & 60.2 & & 7.4 & 1.6 & 0.1 & 52.6 & 25.0 & 0.6 & 2.8 & 90.1 \\
\hline \multirow[t]{9}{*}{ Wheat straw } & $\mathrm{H}_{2} \mathrm{SO}_{4}$ & 0 & 0 & 0.0 & 6.5 & 4.9 & 74.4 & 0.5 & 20.6 & & 0.3 & 50.2 & 14.1 & 1.1 & 5.9 & 92.8 \\
\hline & & 0.010 & 0.020 & 1.1 & 2.8 & 4.0 & 62.3 & 0.2 & 14.6 & & 0.2 & 59.5 & 10.5 & 0.7 & 6.7 & 92.5 \\
\hline & & 0.025 & 0.050 & 2.7 & 2.2 & 2.6 & 43.8 & 0.1 & 1.6 & & 0.2 & 69.5 & 9.9 & 0.5 & 10.9 & 92.6 \\
\hline & $\mathrm{HCl}$ & 0 & 0 & 0.0 & 6.3 & 4.9 & 78.5 & 0.7 & 20.3 & & 0.5 & 48.4 & 15.6 & 1.1 & 5.6 & 92.3 \\
\hline & & 0.020 & 0.020 & 0.8 & 2.5 & 3.4 & 52.2 & 0.1 & 6.6 & & 0.3 & 67.5 & 10.3 & 0.5 & 8.3 & 93.7 \\
\hline & & 0.050 & 0.050 & 2.0 & 2.0 & 2.2 & 35.0 & & 0.6 & & 0.2 & 65.6 & 14.0 & 0.3 & 12.9 & 93.7 \\
\hline & $\mathrm{MgCl}_{2}$ & 0 & & 0.0 & 6.5 & 4.9 & 76.4 & 0.5 & 20.1 & & 0.4 & 48.7 & 15.0 & 1.1 & 6.3 & 92.0 \\
\hline & & 0.010 & & 1.1 & 5.9 & 4.4 & 63.7 & 0.1 & 15.0 & & 0.3 & 55.7 & 13.1 & 0.8 & 7.0 & 91.9 \\
\hline & & 0.025 & & 2.6 & 5.6 & 4.2 & 58.8 & 0.0 & 11.6 & & 0.2 & 61.5 & 11.5 & 0.6 & 7.0 & 92.4 \\
\hline \multicolumn{17}{|c|}{$\begin{array}{l}\text { a pH of slurry at room temperature at start of organosolv experiment. } \\
\text { b pH of organosolv liquor at room temperature after process. } \\
\text { c w/w dry biomass. } \\
\text { d Abbreviations used: arabinan (Ara), xylan (Xyl), mannan (Man), galactan (Gal), glucan (Glu), acid insoluble lignin (AIL), and acid soluble lignin (ASL). } \\
\text { e Ash part of hydrolysis residue (acid soluble part of ash not included). } \\
{ }^{f} \text { Empty cell: concentration below detection limit in hydrolysate. The concentration of rhamnose was below detection limit in all hydrolysates. }\end{array}$} \\
\hline
\end{tabular}
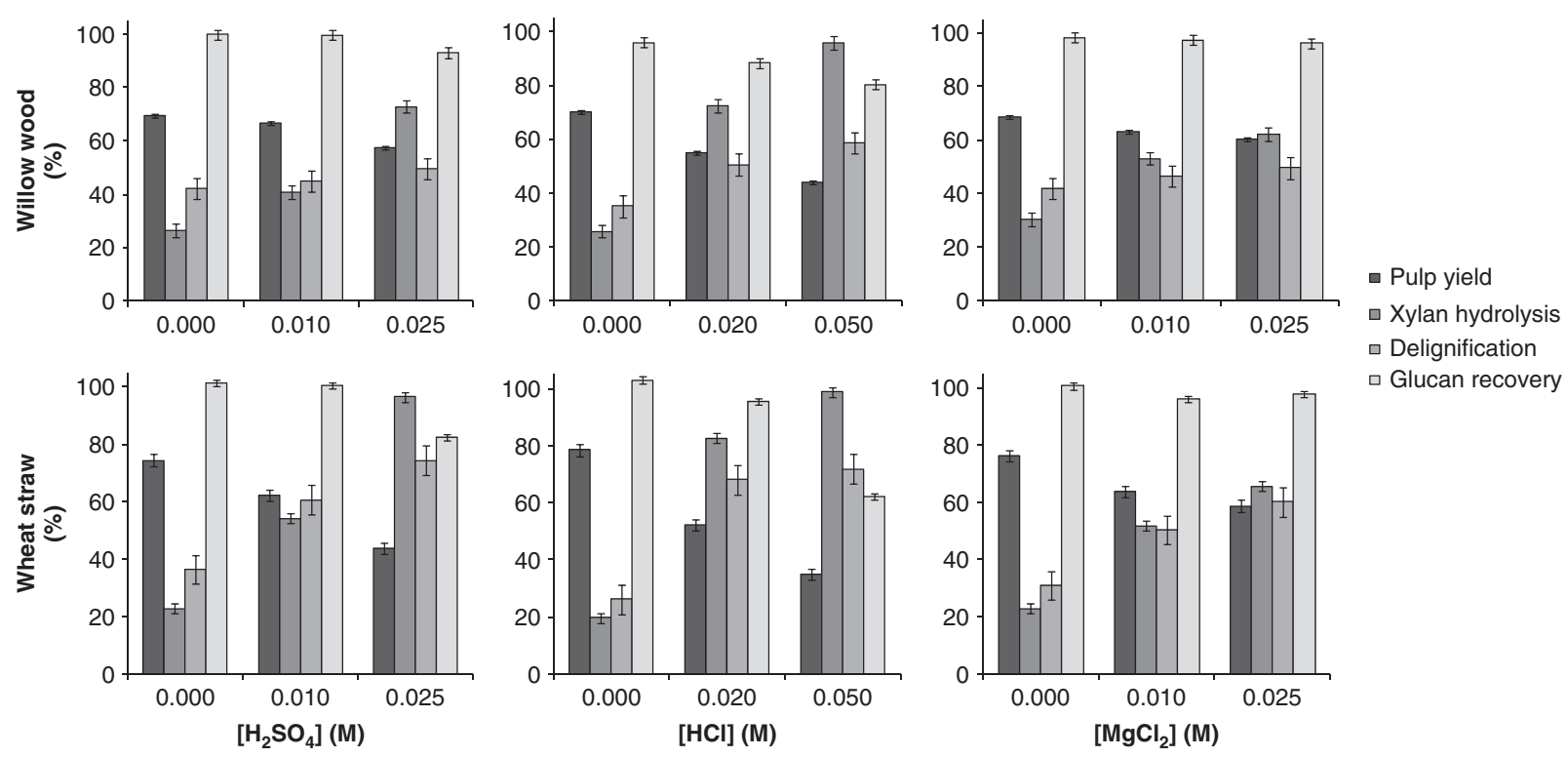

Glucan recovery

Figure 3. Effect of catalyst dose on pulp yield and fractionation of willow wood (top) and wheat straw (bottom).

Figure 4 compares the effect of $\mathrm{H}_{2} \mathrm{SO}_{4}$ and $\mathrm{HCl}$ on organosolv fractionation of both feedstocks based on the final $\mathrm{pH}$ of the organosolv liquor. Figure 4 shows that the pulp yield and xylan hydrolysis degree are well correlated with the $\mathrm{pH}$ of the organosolv liquor. The correlation between $\mathrm{pH}$ of the organosolv liquor and delignification degree is worse (especially for wheat straw).
Figure 4 shows no clear differences between both acid catalysts. Therefore, the effect of the acid catalysts seems to be caused solely by their acidity rather than by the type of anion. Table 2 shows that the addition of $\mathrm{HCl}$ reduces the $\mathrm{pH}$ of the organosolv liquor to a substantially larger extent than $\mathrm{H}_{2} \mathrm{SO}_{4}$ at equal normality. Therefore, it can be concluded that acid strength (pKa) of both 

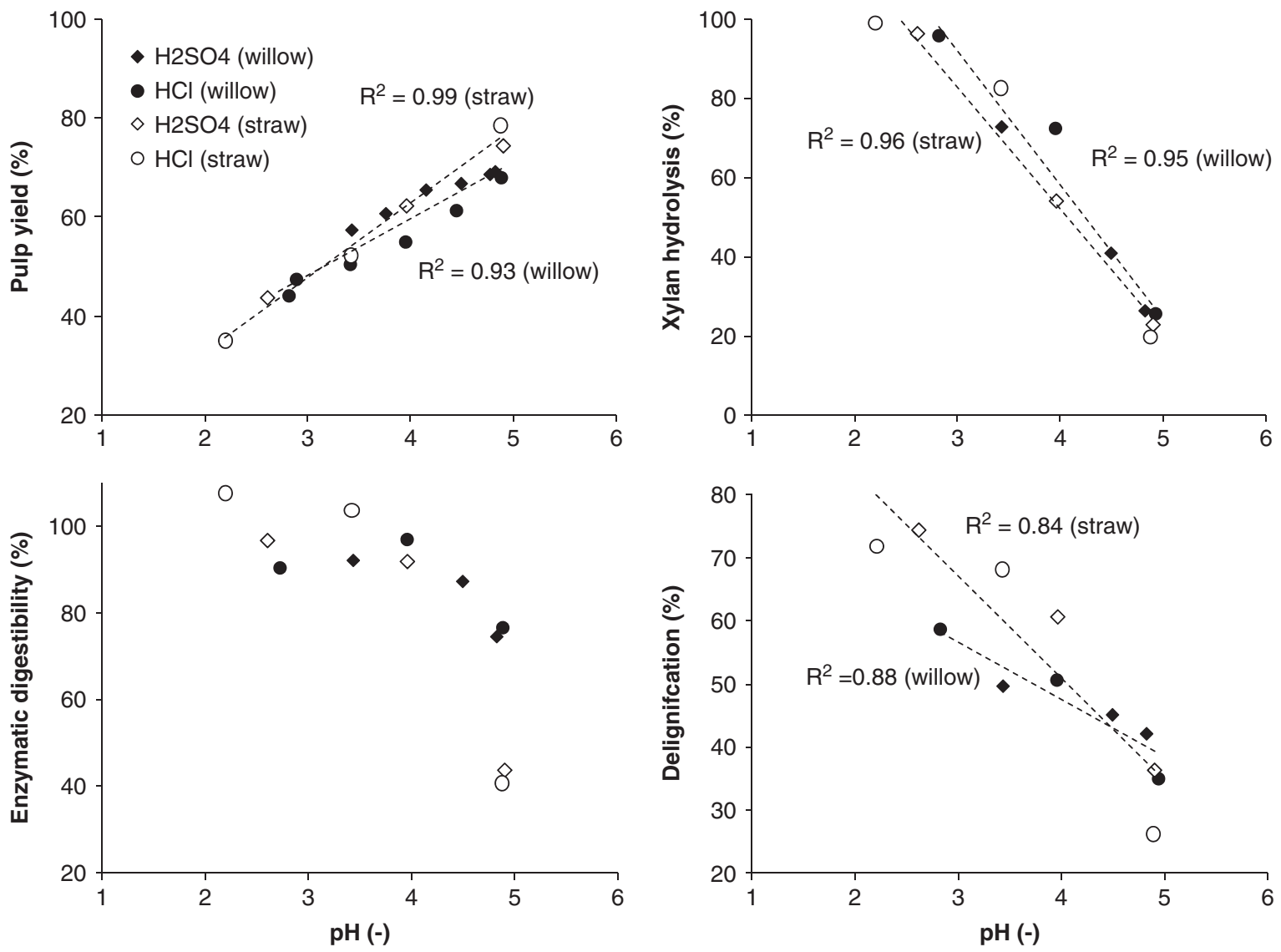

Figure 4. Effect of acid catalysts on fractionation and enzymatic digestibility as function of the final pH of the organosolv liquor.

acids differs. In an aqueous environment both $\mathrm{H}_{2} \mathrm{SO}_{4}$ and $\mathrm{HCl}$ are strong acids resulting in complete dissociation. However, in aqueous ethanol the second dissociation step of $\mathrm{H}_{2} \mathrm{SO}_{4}$ seems to be weak resulting in higher $\mathrm{pH}$ values of the organosolv liquor than for $\mathrm{HCl}$ at equal normality (Table 2). Overall, addition of $\mathrm{HCl}$ has a larger effect on the pulp yield (Fig. 2 and Table 2 ) and fractionation (Fig. 3) than the addition of an equal dose of $\mathrm{H}_{2} \mathrm{SO}_{4}$, expressed in terms of normality.

Finally, the influence of an acid catalyst on xylan hydrolysis and delignification is more pronounced for wheat straw than for willow (Fig. 3). Table 2 shows that the final pH of any organosolv liquor from catalytic willow wood pretreatment is higher than that from wheat straw at a given acid dose. This difference is probably caused by the somewhat higher acid neutralization capacity of willow wood compared with that of wheat straw (see section 'feedstocks'). It seems that the mineral fraction of willow neutralizes the added acid catalyst to a larger extent, thereby reducing its effect on fractionation.

\section{$\mathrm{MgCl}_{2}$}

The use of the third catalyst, $\mathrm{MgCl}_{2}$, also increases xylan hydrolysis and delignification (Fig. 3). Table 2 shows that addition of $\mathrm{MgCl}_{2}$ decreases the $\mathrm{pH}$ of the organosolv slurry at the start of an organosolv experiment. For both feedstocks, mixtures containing $0.025 \mathrm{~mol} \mathrm{~L}^{-1} \mathrm{MgCl}_{2}$ have a $\mathrm{pH}$ of about 1 unit lower than those without any catalyst added. It remains unclear how a neutral salt like $\mathrm{MgCl}_{2}$ lowers the $\mathrm{pH}$, although Paszner and Cho hypothesized that adsorption of $\mathrm{Mg}^{2+}$ on the carboxylic acid groups of the biomass causes release of protons. ${ }^{27}$ On the other hand, the type of anion in Mg-salts has also been reported to play a role, with $\mathrm{Cl}^{-}$as most effective anion tested. ${ }^{22}$ Moreover, the addition of a salt influences the ionic strength of the organosolv liquor. During $\mathrm{MgCl}_{2}$-catalysed organosolv fractionation, the $\mathrm{pH}$ of the organosolv liquor decreases because of the formation of organic acids. In contrast, the $\mathrm{pH}$ of the organosolv liquor increases during acid-catalyzed organosolv fractionation due to neutralization by the ash component. Overall, during the total process the $\mathrm{pH}$ of the $\mathrm{MgCl}_{2}$-catalyzed experiments remains relatively constant and high compared with acid-catalyzed experiments (Table 2).

Maximum fractionation using $\mathrm{MgCl}_{2}$ has been obtained at its highest dose $\left(0.025 \mathrm{~mol} \mathrm{~L}^{-1}\right.$ or $\sim 2.7 \% \mathrm{w} / \mathrm{w}$ dry biomass). For willow wood, $62 \%$ xylan hydrolysis and $49 \%$ delignification have been obtained. For wheat straw, 66\% xylan hydrolysis and $60 \%$ delignification. The use of $\mathrm{MgCl}_{2}$ fractionates wheat straw to a smaller extent than the use of the acid catalysts (maxima obtained with acid catalysts: $99 \%$ xylan hydrolysis, and $74 \%$ delignification). This results in a lower glucan content of the pulp obtained (up to $70 \%$ and $62 \%$ for acid catalysts and $\mathrm{MgCl}_{2}$, respectively). In contrast to the acid catalysts, no significant glucan hydrolysis is observed at any dose of $\mathrm{MgCl}_{2}$ added. The glucan recovery at the highest catalyst dose is still 96\% (willow wood) and 98\% (wheat straw).

$\mathrm{MgCl}_{2}$ seems to have a less pronounced effect than acid catalysts on xylan hydrolysis of willow wood compared with delignification. For example, willow wood has been delignified for about $50 \%$ using either $0.025 \mathrm{~mol} \mathrm{~L}^{-1} \mathrm{H}_{2} \mathrm{SO}_{4}, 0.02 \mathrm{~mol} \mathrm{~L}^{-1} \mathrm{HCl}$, or $0.025 \mathrm{~mol} \mathrm{~L}^{-1} \mathrm{MgCl}_{2}$. At these catalyst concentrations, the xylan 

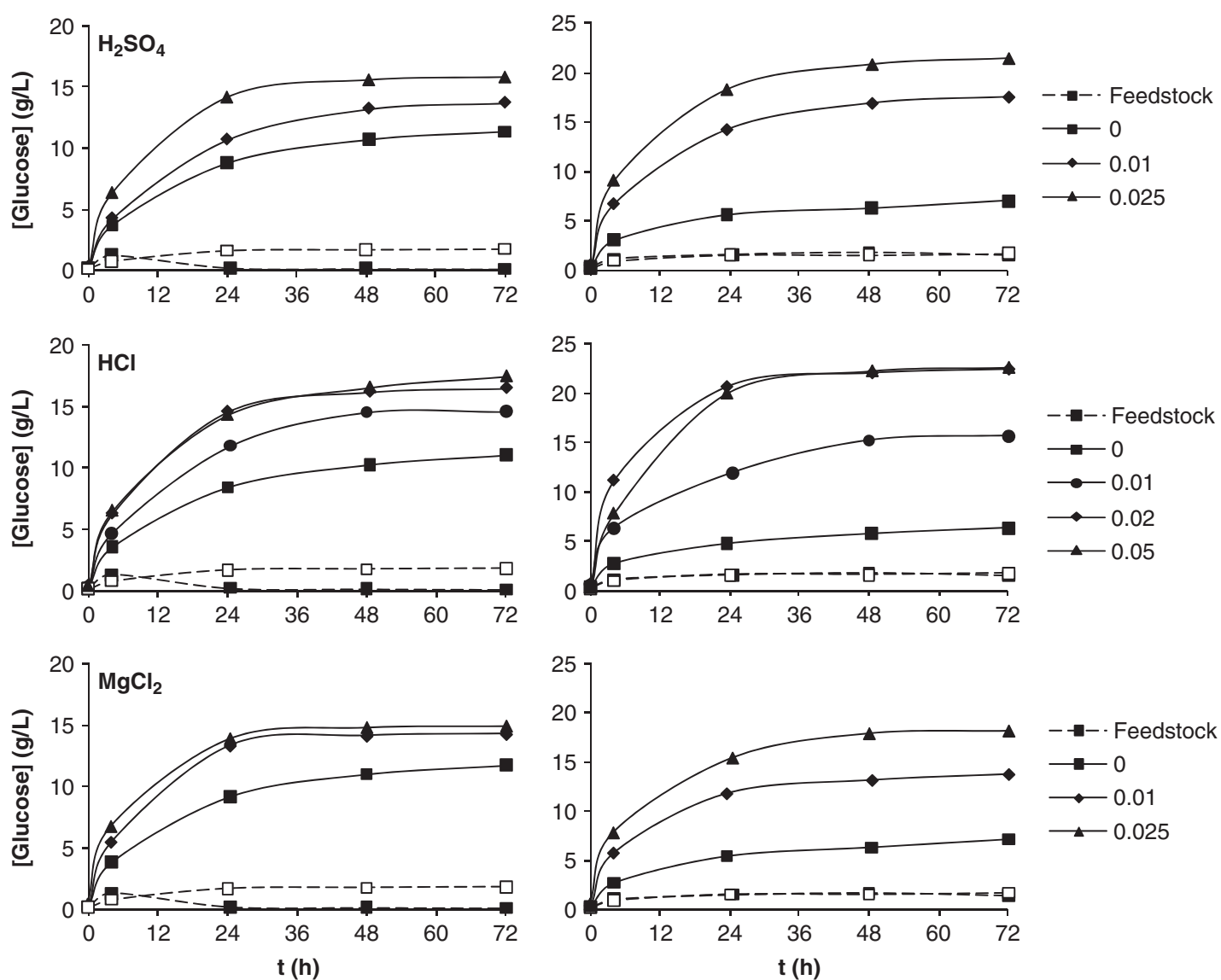

Figure 5. Average glucose concentration during enzymatic hydrolysis of raw materials and pretreated biomass substrates ( $\mathrm{n}=2$ ); Biomass: willow wood (left) and wheat straw (right). Antibiotic applied: PenStrep (solid symbols) or sodium azide (open symbols).

hydrolysis degree is $73 \%$ for both $\mathrm{H}_{2} \mathrm{SO}_{4}$ and $\mathrm{HCl}$ and only $62 \%$ for $\mathrm{MgCl}_{2}$. This difference in behaviour between $\mathrm{MgCl}_{2}$ and acid catalysts has also been mentioned by others for softwoods. ${ }^{19,22}$ For wheat straw, this apparent difference in effects of both types of catalysts could not be observed in the data presented.

\section{Enzymatic hydrolysis of (pretreated) biomass}

The enzymatic hydrolysis profiles of the feedstocks and selected pretreated materials are given in Fig. 5. Glucose concentrations follow the typical patterns observed during enzymatic cellulose hydrolysis, 15,16,29,30 except for the willow wood raw material. During enzymatic hydrolysis of this substrate, the glucose concentration drops unexpectedly after $4 \mathrm{~h}$ in spite of the PenStrep antibiotic applied to prevent the growth of sugar-consuming bacteria. Repetition of the experiment as well as doubling the amount of antibiotic gave similar results. Therefore, the enzymatic hydrolysis of both feedstocks was repeated using $0.02 \% \mathrm{w} / \mathrm{v}$ sodium azide instead of PenStrep according to NREL/TP-510$42629^{25}$. No sugar consumption occurred when $\mathrm{NaN}_{3}$ was used (Fig. 5). For both feedstocks, the maximum glucose concentrations (obtained using $\mathrm{NaN}_{3}$ ) correspond to an enzymatic digestibility of $18 \%$ (willow wood) and 15\% (wheat straw). No indications of sugar consumption were observed during enzymatic hydrolysis of any other substrate.

\section{Non-catalytic organosolv}

Organosolv pretreatment improves the enzymatic digestibility of both willow wood and wheat straw under all conditions studied.
Following non-catalytic organosolv pretreatment, maximum glucose concentrations during enzymatic hydrolysis increases from $2 \mathrm{~g} \mathrm{~L}^{-1}$ for non-treated willow wood to $11 \mathrm{~g} \mathrm{~L}^{-1}$ for pretreated willow wood (Fig. 5). This corresponds to an average enzymatic digestibility of the pulps of $76.2 \pm 1.6 \%$ glucose based on the glucan content of the pulp ( $74.0 \pm 2.5 \%$ based on the raw material) (Fig. 6). Non-catalytic organosolv pretreatment of wheat straw increases enzymatic glucose concentrations from $2 \mathrm{~g} \mathrm{~L}^{-1}$ (raw material) to $7 \mathrm{~g} \mathrm{~L}^{-1}$. The corresponding glucose yields are $43.4 \pm 2.5 \%$ (pulpbased) and $44.1 \pm 2.0 \%$ (raw material-based). The substantially higher enzymatic digestibility of pretreated willow wood compared with wheat straw resulting from non-catalytic organosolv is opposite to the relative lignin content of both pulps. The average lignin content of non-catalytically pretreated willow wood is $26 \%$ versus $16 \%$ for wheat straw (Table 2 ). Therefore, the higher enzymatic digestibility of pretreated willow wood seems to be caused by other properties of the pulp such as the lower xylan content of pretreated willow wood compared with wheat straw (12 and 20\% $\mathrm{w} / \mathrm{w}$ dry biomass, respectively). Finally, the spread in enzymatic digestibility results of non-catalytic organosolv pretreatment has been used as an estimate of the experimental error made in Fig. 6 .

\section{Catalytic organosolv}

The use of catalysts further improves the enzymatic digestibility of both feedstocks (Figs 5 and 6). Maximum glucose concentrations during enzymatic hydrolysis increase to $14-17 \mathrm{~g} \mathrm{~L}^{-1}$ for willow wood and $16-23 \mathrm{~g} \mathrm{~L}^{-1}$ for wheat straw following catalytic organosolv pretreatment (Fig. 5). Maximum glucose concentrations were 

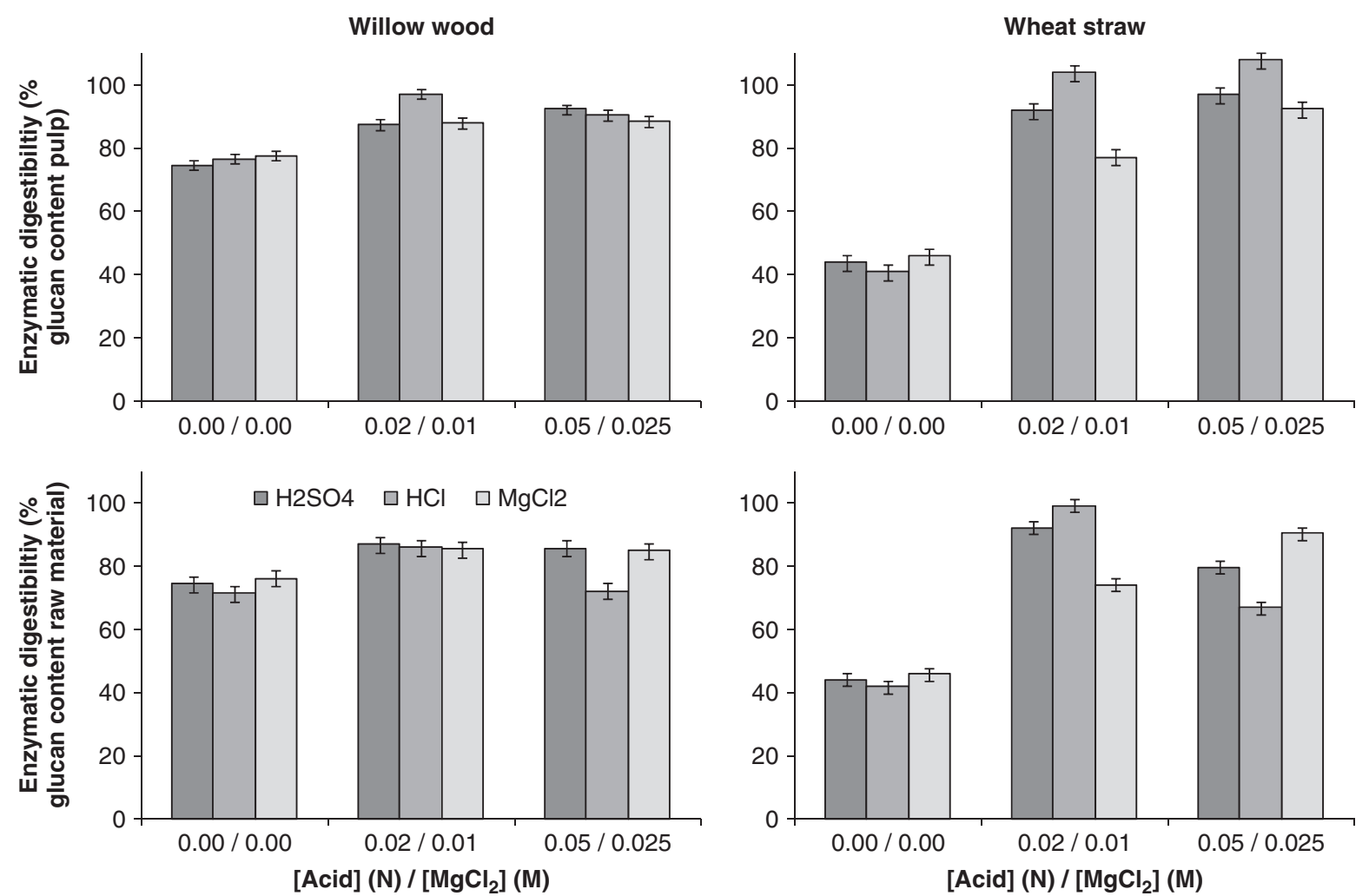

Figure 6. Maximum enzymatic digestibility based on glucan content of either the pretreated biomass (top) or the biomass feedstock (bottom).

obtained with $0.05 \mathrm{~mol} \mathrm{~L}^{-1} \mathrm{HCl}$ for both raw materials $\left(17 \mathrm{~g} \mathrm{~L}^{-1}\right.$ for willow wood and $23 \mathrm{~g} \mathrm{~L}^{-1}$ for wheat straw).

The corresponding glucose yields by enzymatic hydrolysis are 87-97\% (willow wood) and 77-108\% (wheat straw) based upon the glucan content of pretreated materials (Fig. 6, top). For both feedstocks, maximum enzymatic glucose yields were obtained with $\mathrm{HCl}$ followed by $\mathrm{H}_{2} \mathrm{SO}_{4}$ and $\mathrm{MgCl}_{2}$. Remarkably, wheat straw shows a higher digestibility after catalytic organosolv than willow wood at all catalyst doses (except $0.01 \mathrm{~mol} \mathrm{~L}^{-1} \mathrm{MgCl}_{2}$ ), while after non-catalytic organosolv wheat straw has a substantially lower enzymatic digestibility. For the acid catalysts, their larger influence on the fractionation of wheat straw compared with willow wood because of differences in acid neutralization capacity, as discussed above, is probably contributing to substantial enhancement of the enzymatic digestibility of wheat straw. Table 2 shows that the xylan content of pretreated wheat straw is more strongly reduced by acid catalysts than that of willow wood. In the case of raw materials and pulps resulting from non-catalytic organosolv, the xylan content of wheat straw is higher than that of willow wood. In the case of pulps resulting from catalytic organosolv in which a high dose of acid was applied, the xylan content of wheat straw is lower than that of willow wood. The enzymatic digestibility of pretreated willow wood seems to reach an optimum at a final $\mathrm{pH}$ of the organosolv liquor of 4.0 (Fig. 4). At lower pH values, the enzymatic digestibility decreases, in contrast to that of wheat straw.

The enzymatic digestibility of wheat straw after pretreatment with 0.02 or $0.05 \mathrm{~mol} \mathrm{~L}^{-1} \mathrm{HCl}$ slightly exceeds the theoretical maximum of $100 \%$ (104 and $108 \%$, respectively). This might due to an analytical overestimation of the glucose concentration in the hydrolysate. In the colorimetric method used, minor absorption of non-glucose components is known to occur, as was discussed in earlier work. ${ }^{30}$ For verification, the hydrolysates obtained after $72 \mathrm{~h}$ of enzymatic hydrolysis of the 0.02 and $0.05 \mathrm{~mol} \mathrm{~L}^{-1} \mathrm{HCl}$ pretreated wheat straw samples were also analyzed by HPAEC-PAD for their glucose concentration. It was found that the colorimetric method used overestimated the glucose concentrations in these samples by (only) 3 and 1\%, respectively. Another effect that might play a role is the experimental error in the determination of the glucan content of the substrate.

\section{Feedstock-based enzymatic glucose yields}

The overall enzymatic glucose yield based on the composition of the feedstocks was determined taking into account glucan hydrolysis during organosolv fractionation (Fig. 6, bottom). Most significant deviations from the enzymatic glucose yield based on the composition of the substrate occur at high acid catalyst doses (i.e. doses at which significant glucan hydrolysis occurred during organosolv). Most noticeably, the enzymatic digestibility of wheat straw at $0.05 \mathrm{~mol} \mathrm{~L}^{-1} \mathrm{HCl}$ expressed on the glucan content of the raw material is only $67 \%$ compared to $108 \%$ expressed on the glucan content of the pulp due to the $38 \%$ glucan hydrolysis during organosolv fractionation. The maximum overall glucose yield obtained is $87 \%$ (willow wood, $0.01 \mathrm{~mol} \mathrm{~L}^{-1} \mathrm{H}_{2} \mathrm{SO}_{4}$ ) and $99 \%$ (wheat straw, $0.02 \mathrm{~mol} \mathrm{~L}^{-1} \mathrm{HCl}$ ). For willow wood, other catalyst doses give similar yields, i.e. $0.02 \mathrm{~mol} \mathrm{~L}^{-1} \mathrm{HCl}(86 \%), 0.05 \mathrm{~mol} \mathrm{~L}^{-1}$ $\mathrm{H}_{2} \mathrm{SO}_{4}$ (86\%) and 0.01 and $0.025 \mathrm{~mol} \mathrm{~L}^{-1} \mathrm{MgCl}_{2}$ (85\%). Therefore, no optimum catalyst can be selected for willow wood based on the overall enzymatic glucose yield. For wheat straw, the optimum enzymatic glucose yield of this study is comparable with, for example, yields reported in the literature using dilute (organic) acid pretreatment, ${ }^{35}$ dilute $\mathrm{H}_{2} \mathrm{SO}_{4}$ impregnation followed by steam explosion, ${ }^{24}$ or mild oxidation with hydrogen peroxide. ${ }^{24}$ 

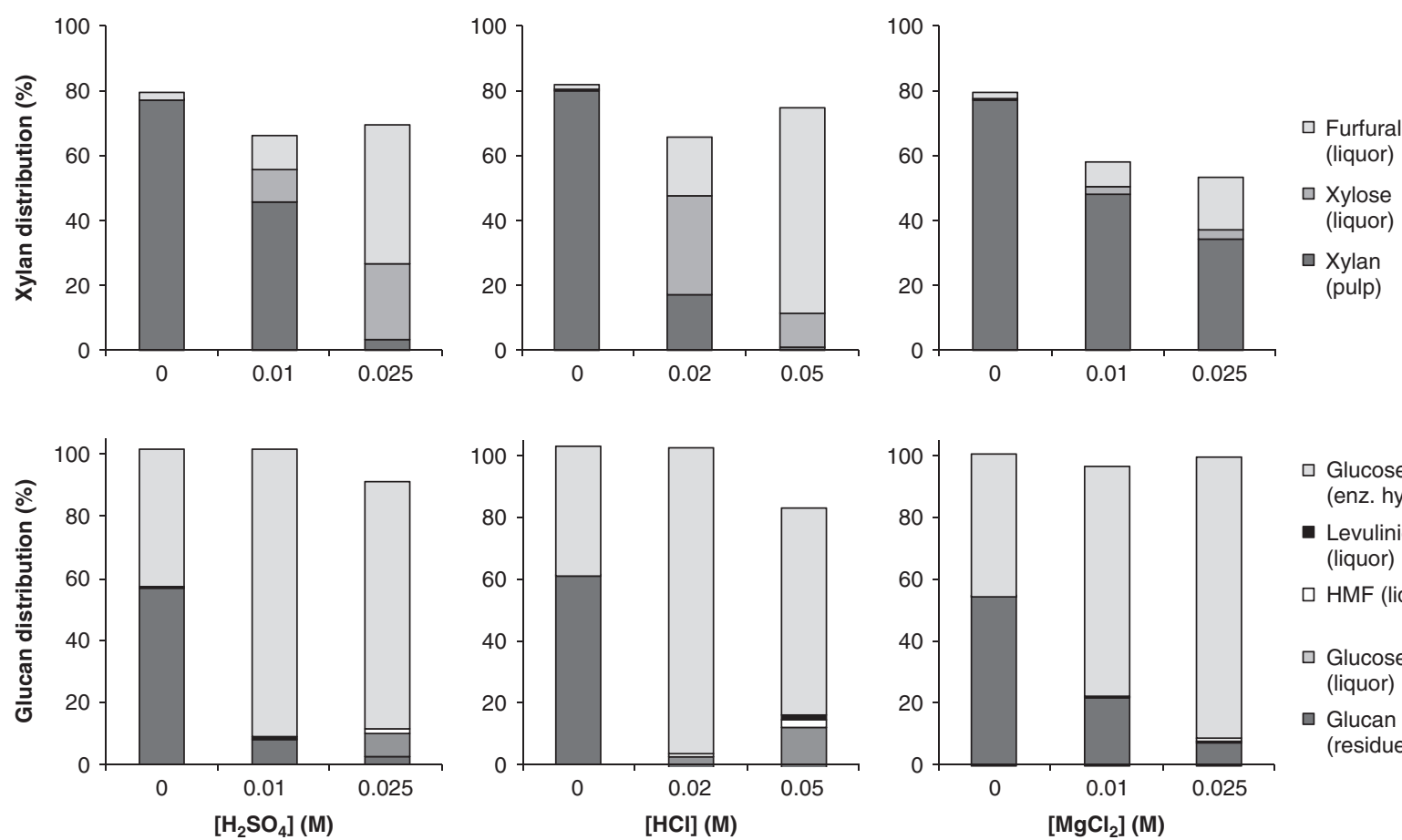

$\square$ Glucose (enz. hydr.)

- Levulinic acid (liquor)

$\checkmark$ HMF (liquor)

$\square$ Glucose (liquor)

$\square$ Glucan (residue)

Figure 7. Product distribution xylan (top) and glucan (bottom) for wheat straw (mol\%). Components included for xylan: xylose and furfural in organosolv liquor and xylan in organosolv pretreated wheat straw. For glucan: glucose, HMF and levulinic acid in organosolv liquor, glucose in enzymatic hydrolysate, and glucan in solid residue after enzymatic hydrolysis.

\section{Xylanase activity}

The Accellerase 1500 enzyme cocktail used also exhibits xylanase activity according to the supplier. In the literature a xylanase activity of $75 \mathrm{IU} \mathrm{mL}^{-1}$ has been reported. ${ }^{36}$ HPAEC-PAD analysis of the $72 \mathrm{~h}$ hydrolysate of the $0.02 \mathrm{~mol} \mathrm{~L}^{-1} \mathrm{HCl}$ pretreated wheat straw substrate resulted in $2.0 \mathrm{~g} \mathrm{~L}^{-1}$ xylose and $91 \%$ enzymatic xylose yield based on the xylan content of the pulp. Since the xylan hydrolysis degree during organosolv fractionation at these conditions is $83 \%$, the additional enzymatic xylose yield based on the composition of the feedstock is only $16 \%$. In total, $99 \%$ of the xylan present in the wheat straw raw material is converted at these conditions.

Overall, it can be concluded that application of all three catalysts tested improves the susceptibility of both feedstocks for hydrolytic enzymes. Underlying mechanistic factors most likely include improved hemicellulose hydrolysis and enhanced delignification resulting in better cellulose accessibility for enzymes and less non-productive binding of enzymes to lignin. ${ }^{4}$

\section{Yields sugar products wheat straw fractionation}

Figure 7 shows the yields of glucan- and xylan-derived products after organosolv fractionation of wheat straw followed by enzymatic hydrolysis of the pulp (expressed in mol\%). Optimum glucose yields were obtained at medium acid catalyst doses and the highest $\mathrm{MgCl}_{2}$ dose. Maximum glucose yield in a single product stream occurs at $0.02 \mathrm{~mol} \mathrm{~L}^{-1} \mathrm{HCl}(99 \%$, enzymatic hydrolysate). The highest yields of monomeric xylose in the organosolv liquor occur at $0.025 \mathrm{~mol} \mathrm{~L}^{-1} \mathrm{H}_{2} \mathrm{SO}_{4}(24 \%)$ and $0.02 \mathrm{~mol} \mathrm{~L}^{-1} \mathrm{HCl}(30 \%)$. Together with xylose formed during enzymatic hydrolysis of the $0.02 \mathrm{~mol} \mathrm{~L}^{-1} \mathrm{HCl}$ pretreated wheat straw the total xylose yield is $46 \%$. In addition, $18 \%$ of the xylan is converted into furfural at this condition. Furfural is the major product from xylan in acidcatalyzed organosolv experiments (up to $63 \%$ at $0.05 \mathrm{~mol} \mathrm{~L}^{-1} \mathrm{HCl}$ ).
The use of $\mathrm{MgCl}_{2}$ leads to very low yields of monomeric xylose (max 3\%).

For glucan, the balances are roughly closed except at severe hydrolysis conditions $\left(0.05 \mathrm{~N} \mathrm{H}_{2} \mathrm{SO}_{4}\right.$ and $\left.\mathrm{HCl}\right)$. At these conditions, substantial hydrolysis of cellulose occurs, probably with subsequent degradation of glucose in the organosolv liquor. Since the yields of the glucose derivatives HMF and levulinic acid are small (max 2.6 and $1.3 \%$ at $0.05 \mathrm{~mol} \mathrm{~L}^{-1} \mathrm{HCl}$, respectively), HMF and glucose have probably reacted away and formed so-called humins or lignin condensation products. ${ }^{1,37}$ For xylan, balances are less complete than for glucose (losses between $18 \%$ and $47 \%$ ). First of all, furfural formed has been reported to react further including formation of humins ${ }^{37}$ and lignin-furfural condensation products, ${ }^{30}$ especially at acidic conditions. For the non-acid catalysed experiments, oligomeric xylose fragments are probably present in significant amounts, as was discussed in earlier work. ${ }^{30}$

\section{Comparison of catalysts}

As discussed above, the effect of the acid catalysts $\mathrm{H}_{2} \mathrm{SO}_{4}$ and $\mathrm{HCl}$ seems primarily due to their effect on the $\mathrm{pH}$ of the organosolv liquor rather than the type of acid. In addition, similar results in terms of fractionation degree and enzymatic hydrolysis yields have been obtained with both catalysts, especially for willow wood. Since $\mathrm{H}_{2} \mathrm{SO}_{4}$ has been found to be a weaker acid than $\mathrm{HCl}$ in aqueous ethanol, a higher dose of this catalyst is required than of $\mathrm{HCl}$. On the other hand, $\mathrm{H}_{2} \mathrm{SO}_{4}$ is cheaper and less corrosive than $\mathrm{HCl}$.

The use of $\mathrm{MgCl}_{2}$ leads to lower delignification and xylan hydrolysis degrees than the acid catalysts. In addition, the enzymatic glucose yields obtained using $\mathrm{MgCl}_{2}$ are slightly lower than those obtained using acid catalysts (within the range of process conditions tested). On the other hand, a benefit of $\mathrm{MgCl}_{2}$ might be that it can yield similar enzymatic glucose yields to the 
acid catalysts, while retaining more xylan in the pulp (i.e. lower xylan hydrolysis degree). For example, willow wood pretreated using $0.01 \mathrm{~mol} \mathrm{~L}^{-1} \mathrm{MgCl}_{2}$ results in $85 \%$ overall enzymatic glucose yield at relatively low xylan hydrolysis (52\%). A similar enzymatic glucose yield $(86 \%)$ has been found for willow wood pretreatment using $0.02 \mathrm{~mol} \mathrm{~L}^{-1} \mathrm{HCl}$, but at substantially higher xylan hydrolysis (83\%). In a process scheme in which the pulp is enzymatically hydrolyzed and the resulting $\mathrm{C} 5$ and $\mathrm{C} 6$ sugars are cofermented, this could potentially imply higher yields of bioethanol.

This study has focused on the effect of different catalysts on organosolv pretreatment of both a hardwood and a herbaceous crop at a single set of process conditions, such as temperature and solvent: water ratio. A next step would be to perform an optimization study taking into account all other major process variables in addition to catalyst dose. Final selection of the optimum catalyst should be performed based on an economic analysis of the process including cost of catalyst, additional costs caused by corrosive-resistant materials, and product values.

\section{CONCLUSIONS}

The effect of the catalysts $\mathrm{H}_{2} \mathrm{SO}_{4}, \mathrm{HCl}$, and $\mathrm{MgCl}_{2}$ on ethanol-based organosolv pretreatment of willow wood and wheat straw was studied and compared. For willow wood, maximum enzymatic cellulose hydrolysis was obtained using $0.01 \mathrm{~mol} \mathrm{~L}^{-1} \mathrm{H}_{2} \mathrm{SO}_{4}$ as catalyst $(87 \%$, together with $73 \%$ xylan hydrolysis and $51 \%$ delignification). For wheat straw, the maximum enzymatic glucose yield obtained based on the glucan content of the feedstock was 99\% (together with $83 \%$ xylan hydrolysis and $68 \%$ delignification). For comparison, non-catalytic organosolv at identical conditions yielded $74 \%$ and $44 \%$ enzymatic glucose yield based on the glucan content of the feedstock for willow wood and wheat straw, respectively (28\% and $22 \%$ xylan hydrolysis, $40 \%$ and $31 \%$ delignification). The reverse in relative susceptibility of both feedstocks for enzymatic hydrolysis, comparing non-catalytic and acid catalyzed-organosolv pretreatment, seems to be due to a more pronounced reduction by catalysts of the xylan content of wheat straw than that of willow wood. The effect of the acid catalysts was found to be primarily due to their effect on the $\mathrm{pH}$ of the organosolv liquor rather than the type of anion. The use of $\mathrm{MgCl}_{2}$ was found to enhance fractionation and enzymatic digestibility to a lesser extent than both acid catalysts. On the other hand, $\mathrm{MgCl}_{2}$ seems to more selectively promote delignification and enzymatic digestibility of willow wood. In general, application of catalysts in organosolv pretreatment was found to improve fractionation and enzymatic digestibility, especially for wheat straw. Thus, the use of catalysts can contribute to achieving maximum utilization and valorization of lignocellulosic biomass in organosolv-based biorefineries.

\section{ACKNOWLEDGEMENTS}

This research was funded by the Dutch Ministry of Economic Affairs, Agriculture, and Innovation within the framework of the Dutch national project LignoValue (contract no. EOSLT-05011) and as part of the ECN biomass research program.

\section{REFERENCES}

1 Zhao X, Cheng Kand Liu D, Organosolv pretreatment of lignocellulosic biomass for enzymatic hydrolysis. Appl Microbiol Biotechnol 82:815-827 (2009).
2 Kumar P, Barrett DM, Delwiche MJ and Stroeve P, Methods for pretreatment of lignocellulosic biomass for efficient hydrolysis and biofuel production. Ind Eng Chem Res 48:3713 - 3729 (2009).

3 Muurinen $\mathrm{E}$, Organosolv pulping. A review and distillation study related to peroxyacid pulping. PhD thesis University of Oulu, Oulu, Finland (2000).

4 Alvira $\mathrm{P}$, Tomás-Pejó $\mathrm{E}$, Ballesteros $\mathrm{M}$ and Negro MJ, Pretreatment technologies for an efficient bioethanol production process based on enzymatic hydrolysis: a review. Bioresource Technol 101:4851-4861 (2010).

5 MacFarlane AL, Prestidge R, Farid MM and Chen JJ, Dissolved air flotation: a novel approach to recovery of organosolv lignin. Chem Eng J 148:15-19 (2009).

6 Gosselink RJA, Abächerli A, Semke H, Malherbe R, Käuper P, Nadif A, et al, Analytical protocols for characterisation of sulphur-free lignin. Ind Crop Prod 19:271-281 (2004).

$7 \mathrm{Xu} \mathrm{F}$, Comparative study of organosolv lignins from wheat straw. Ind Crop Prod 23:180-193 (2006).

8 Bozell JJ, Holladay JE, Johnson D and White JF, Top value-added chemicals from biomass. Volume II-results of screening for potential candidates from biorefinery lignin. Report No. PNNL16983 (2007).

9 Lora JH and Glasser WG, Recent industrial applications of lignin: a sustainable alternative to nonrenewable materials. J Polym Environ 10:39-47 (2002).

10 Pan X, Kadla JF, Ehara K, Gilkes N and Saddler JN, Organosolv ethanol lignin from hybrid poplar as a radical scavenger: relationship between lignin structure, extraction conditions, and antioxidant activity. J Agric Food Chem 54:5806-5813 (2006).

11 Zakzeski J, Bruijnincx PCA, Jongerius AL and Weckhuysen BM, The catalytic valorization of lignin for the production of renewable chemicals. Chem Rev 110:3552-3599 (2010).

12 Arato C, Pye EK and Gjennestad G, The lignol approach to biorefining of woody biomass to produce ethanol and chemicals. Appl Biochem Biotechnol 123:871-882 (2005).

13 Pan X, Arato C, Gilkes N, Gregg D, Warren M, Pye K, et al, Biorefining of softwoods using ethanol organosolv pulping-preliminary evaluation of process streams for manufacture of fuel-grade ethanol and co-products. Biotechnol Bioeng 90:473-481 (2005).

14 Pan X, Gilkes N, Kadla JF, Pye K, Saka S, Gregg D, et al, Bioconversion of hybrid poplar to ethanol and co-products using an organosolv fractionation process: optimization of process yields. Biotechnol Bioeng 94:851-861 (2006).

15 Diaz MJ, Huijgen WJJ, Van der Laan RR, Reith JH, Cara C and Castro E, Organosolv pretreatment of olive tree biomass for fermentable sugars. Holzforschung 65:177-183 (2011).

16 Pan X, Xie D, Yu RW, Lam D and Saddler JN, Pretreatment of lodgepole pine killed by mountain beetle using the ethanol organosolv process: fractionation and process optimization. Ind Eng Chem Res 46:2609-2617 (2007).

17 Brosse N, Sannigraphi P and Ragauskas A, Pretreatment of Miscanthus $x$ giganteus using the ethanol organosolv process for ethanol production. Ind Eng Chem Res 48:8328-8334 (2009).

18 Mesa L, GonzalezE, Cara C, Ruiz E, Castro E and Mussatto SI, An approach to optimization of enzymatic hydrolysis from sugarcane bagasse based on organosolv pretreatment. J Chem Technol Biotechnol 85:1092-1098 (2010).

19 Del Rio LF, Chandra RP and Saddler JN, The effect of varying organosolv pretreatment chemicals on the physicochemical properties and cellulolytic hydrolysis of mountain pine beetle-killed lodgepole pine. Appl Biochem Biotechnol 161:1-21 (2010).

20 El Hage R, Brosse N, Sannigrahi P and Ragauskas A, Effects of process severity on the chemical structure of Miscanthus ethanol organosolv lignin. Polym Degrad Stabil 95:997-1003 (2010).

21 Park N, Kim H-K, Koo B-W, Yeo H and Choil-G, Organosolv pretreatment with various catalysts for enhancing enzymatic hydrolysis of pitch pine (Pinus rigida). Bioresource Technol 101:7046-7053 (2010).

22 Yawalata D and Paszner L, Anionic effect in high concentration alcohol organosolv pulping. Holzforschung 58:1-6 (2004).

23 Yawalata D and Paszner L, Cationic effect in high concentration alcohol organosolv pulping: the next generation biorefinery. Holzforschung 58:7-13 (2004).

24 Talebnia F, Karakashev D and Angelidaki I, Production of bioethanol from wheat straw: an overview on pretreatment, hydrolysis and fermentation. Bioresource Technol 101:4744-4753 (2010). 
25 National Renewable Energy Laboratory (NREL), Chemical analysis and testing laboratory analytical procedures. NREL, Golden, CO, USA. http://www.nrel.gov/biomass/analytical_procedures.html (2009).

26 European Committee for Standardization. CEN/TS 14429: Characterization of waste-leaching behaviour tests - influence of $\mathrm{pH}$ on leaching with initial acid/base addition (2005).

27 Paszner L and Cho HJ, Organosolv pulping: acidic catalysis options and their effect on fiber quality and delignification. TAPPI J 72:135-142 (1989).

28 Garrote G, Domínguez H and Parajó JC, Hydrothermal processing of lignocellulosic materials. Holz als Roh- und Werkstoff 57:191-202 (1999).

29 Esteghlalian AR, Bilodeau M, Mansfield SD and Saddler JN, Do enzymatic hydrolyzability and Simons' stain reflect the changes in the accessibility of lignocellulosic substrates to cellulase enzymes? Biotechnol Prog 17:1049-1054 (2001).

30 Huijgen WJJ, Reith JH and Den Uil H, Pretreatment and fractionation of wheat straw by an acetone-based organosolv process. Ind Eng Chem Res 49:10132-10140 (2010).
31 Technical Association of the Pulp and Paper Industry (TAPPI), Standard Test Methods. Norcross, GA, USA. http://www.tappi.org/. (2009).

32 Ghose TK, Measurement of cellulase activities. Pure Appl Chem 59:257-268 (1987).

33 Yee HY and Goodwin JF, Evaluation of some factors influencing otoluidine reaction with glucose. Anal Chem 45:2162-2165 (1973).

34 McDonough TJ. The chemistry of organosolv delignification. Report No. 455, IPST technical paper series, Institute of Paper Science and Technology, Atlanta, Georgia. (1992).

35 Kootstra AMJ, Beeftink HH, Scott EL and Sanders JPM, Comparison of dilute mineral and organic acid pretreatment for enzymatic hydrolysis of wheat straw. Biochem Eng J 46:126-131 (2009).

36 Alvira $P$, Negro MJ and Ballesteros M, Effect of endoxylanase and $\alpha$-L-arabinofuranosidase supplementation on the enzymatic hydrolysis of steam exploded wheat straw. Bioresource Technol 102:4552-4558 (2011).

37 Kim D-E and Pan X, Preliminary study on converting hybrid poplar to high-value chemicals and lignin using organosolv ethanol process. Ind Eng Chem Res 49:1215663 (2010). 